\title{
PELATIHAN DAN PENDAMPINGAN BAGI GURU BAHASA INGGRIS DALAM OPTIMALISASI PLATFORM GOOGLE CLASSROOM PADA PROSES KEGIATAN BELAJAR DARING BERBICARA BAHASA INGGRIS
}

\author{
TRAINING AND MENTORING FOR ENGLISH TEACHERS IN GOOGLE \\ CLASSROOM PLATFORM OPTIMALIZATION IN ONLINE LEARNNG ENGLISH \\ SPEAKING ACTIVITIES
}

\author{
Luthfiyatun Thoyyibah", Ratnawati, Desi Nurani \\ Universitas Galuh, JL. R. E. Martadinata N0. 150 Ciamis 46274 Jawa Barat \\ Email: luthfiyatun20@gmail.com \\ (Diterima 26-01-2021; Disetujui 20-03-2021)
}

\begin{abstract}
ABSTRAK
Kegiatan pengabdian ini berjudul Pelatihan dan Pendampingan bagi Guru Bahasa Inggris dalam Optimalisasi Platform Google Classroom pada Proses Kegiatan Belajar Daring Berbicara Bahasa Inggris. Kegiatan ini dilaksanakan berdasarkan analisis situasi dan masalah yang terjadi pada pembelajaran daring di tingkat sekolah menengah pertama di Ciamis khususnya pada pembelajaran berbicara Bahasa Inggris. Kurangnya pengetahuan dan kesadaran tentang pentinya ekplorasi diri, variasi kegiatan pembelajaran dan media pembelajaran dalam pelaksanaan proses belajar dan mengajar daring berbicara Bahasa Inggris ini menjadi salah satu alasan pemilihan konsentrasi kegiatan. Maka dari itu, kegiatan pelatihan dan pendampingan yang diberikan adalah optimalisasi platform Google Classroom pada proses kegiatan belajar daring berbicara bahasa Inggris beseta menejemen kelas daring. Metode yang digunakan dalam pelatihan dan pendampingan tersebut telah dilaksanakan dalam beberapa pertemuan virtual secara interaktif dan dilanjutkan dengan tugas terstruktur sebagai output dari pelatihan dan pendampingan yang telah diberikan. Antusiasme peserta pelatihan dan pendampingan ini dikategorikan baik yang bisa dilihat dari keaktifan peserta bertanya untuk melengkapi luaran kegiatan ini dalam bentuk aktifitas penggunaan di Google Classroom. Selanjutnya, peserta memahami materi kegiatan dengan baik yang direalisasikan dengan output kegiatan yang sesuai dengan pelathan dan bimbingan yang disesuaikan dengan kebutuhan latar belakang mahasiswa masing-masing. Sebagai simpulan, peserta merasa terbantu dengan adanya kegiatan tersebut, hal ini terbukti dari bertambahnya kompetensi pengetahuan dan pedagogis dalam optimalisasi penggunaan Google Classroom serta implementasi praktik menejemen kelas pada kelas berbicara Bahasa Inggrsis secara daring. Untuk kegiatan di masa yang aka datang, kegiatan sejenis dapat dilaksanaan dengan waktu yang lebih lama dan bersifat berkelanjutan.
\end{abstract}

Kata kunci: Google Classroom, Optimalisasi, Platform

\begin{abstract}
The present community service activity is based on an analysis of situations and problems that occur in online English-speaking learning at the junior high school level in Ciamis. Lack of knowledge and awareness of the importance of self-exploration, learning media, and their activities for classroom practices are some reasons for determining the activity. Therefore, the material provided is the optimalization of the Google Classroom platform in speaking skill activities as well as online classroom management. The method used was training and mentoring for the optimalization of the platform which is carried out in several meetings and followed by structured assignments as the outcome of the activity. The enthusiasm of the training and mentoring participants was categorized as good, which could be seen from the active participation during the virtual workshop and their outputs of this activity in the form of using activities in the Google Classroom. Furthermore, participants comprehend what they have learned and practiced during the workshop and what needs to be done with the characteristics of their respective students. In conclusion, the participants felt that they were helped by the indication of the increase in knowledge in optimizing the use of Google Classroom in terms of online classroom management which must be continued. For the next similar activity, it can be carried out for a sustainable and longer time of activity.
\end{abstract}

Keywords: optimization, platform, Google Classroom 
Pelatihan Dan Pendampingan Bagi Guru Bahasa Inggris Dalam Optimalisasi Platform Google Classroom Pada Proses Kegiatan Belajar Daring Berbicara Bahasa Inggris

Luthfiyatun Thoyyibah, Ratnawati, Desi Nurani

\section{PENDAHULUAN}

Dunia pendidikan secara global mengalihkan pelaksanaan pendidikan tatap muka ke pendidikan dalam jaringan untuk memutus mata rantai Covid-19. Tujuan utama dari pendidikan ini adalah tetap berjalannya proses belajar dan mengajar dalam situasi gawat/emergency. Hal tersebut merujuk pendapat Hodges et al. (2020) yang menyatakan bahwa pengubahan mode belajar peserta didik atau siswa secara mendadak agar proses belajar dan mengajar tetap berjalan pada situasi pandemik ini. Dengan demikian, proses kegiatan belajar mengajar yang sebelumnya dilaksanakan pada moda tatap muka, akan tetapi secara drastis berubah menjadi pembelajaran dalam jaringan dengan memanfaatkan teknologi yang ada (Rahiem, 2020). Dengan demikian, proses pengalihan pendidikan yang dalam aktualisasi proses belajar dan mengajar dilaksanakan tanpa adanya perencanaan secara matang baik dari siswa, guru, sarana prasarana dan pemangku kepentingan.

Pada konteks pendidikan Indonesia dalam rangka memutus mata rantai Covid-19, Menteri Pendidikan dan Kebudayaan Indonesia, Nadiem Makarim mengambil langkah tegas dengan menutup sekolah dan melanjutkan pembelajaran dari rumah (CNN Indonesia, 2020). Kebijakan ini juga sejalan dengan kebijakan Menteri Pendidikan dan Kebudayaan mengenai konsep merdeka belajar. Konsep ini memberikan tantangan sendiri terutama bagi guru, dimana seorang guru harus mampu menciptakan suasana belajar yang menyenangkan sehingga guru dituntut untuk memiliki kemampuan dalam mengelola kelas baik secara tatap muka langsung (offline) atau dalam jaringan (online). Oleh karena itu, para guru pun seolah-olah dipaksa harus mengimbangi tuntutan-tuntutan yang terjadi sekarang ini dengan mencari berbagai informasi tambahan mengenai berbagai macam platform pembelajaran daring, metode, dan strategi yang efektif untuk digunakan ketika pembelajaran.

Pada kenyataanya, implementasi pembelajaran daring di daerah Ciamis belum bisa dilaksanakan secara optimal dan efektif karena berbagai faktor. Berdasarkan hasil wawancara dengan ketua MGMP Bahasa Inggris tingkat SMP di Kabupaten Ciamis, beliau mengemukakan beberapa kendala yang dihadapi ketika melaksanakan pembelajaran daring, diantaranya: 1) Kompetensi digital yang belum mumpuni. Hal tersebut terlihat dari perilaku masih rendahnya kompetensi pengoperasian microsoft office dan penggunaan internet pada persiapan proses pembelajaran; 2) Minimnya pengetahuan mengenai platform pembelajaran, pada bagian ini mereka asing dengan beberapa aplikasi pembelajaran yang menarik dan menyenangkan untuk proses kegiatan belajar dan mengajar; 3) Pengelolaan kelas yang belum efektif, hal tersebut terlihat dari proses komunikasi dan interaksi dalam proses belajar dan mengajar berlangsung hanya satu arah 
saja sehingga banyak siswa merasa bosan dan ngantuk dengan pertemaun daring. Selain itu, interaksi kelas yang hanya didominasi oleh guru membuat suasana kelas monoton walaupun komunikasi hanya tertulis; 4) Kegiatan pembelajaran berbicara bahasa Inggris yang masih monoton dan kurang inovatif, hal tersebut terjadi dikarenakan para guru merasa kebingungan bagaimana mengimplementasikan dalam proses belajar mengajar daring; 5) Kendala sinyal oleh sebagian siswa, hal tersebut masih terjadi dengan sebagian kecil siswa karena kondisi geografis tempat tinggal yang tidak terjangkau sinyal.

Berdasarkan fakta di lapangan, mayoritas guru memanfaatkan platform Google Classroom dalam proses belajar dan mengajar di kelas virtual dengan beberapa pertimbangan yakni: (1) salah satu akses laman e-learning yang dapat dimanfaatkan secara gratis dalam mendukung pembelajaran daring, (2) aplikasinya lebih stabil dan low bandwith, (3) fiturnya lebih mudah dipelajari, (4) didukung oleh pemerintah sehingga siswa dapat menggunakan subsisi kuota belajar pada platform tersebut. Disamping itu, beberapa kelebihan dari Google Classroom ini adalah tidak hanya dapat diakses melalui media laptop saja, namun juga sudah tersedia dan bisa diakses dalam bentuk aplikasi android dan Ios. Hal ini dapat mempermudah guru dalam memantau kinerja dan interaksi antara guru dan siswa melalui smartphone maupun gawai berbasis android dan lain sebagainya. Selain itu, guru juga mudah untuk memberikan umpan balik kepada siswa secara langsung dengan efisien, dan berkomunikasi bersama siswa tanpa terbatas oleh ruang dan waktu. Selanjutnya, guru dapat mengatur kelas, memanfaatkan waktu dan meningkatkan kualitas komunikasi dengan siswa (Latif, 2016). Namun pada kenyataanya, saat ini belum banyak guru-guru yang memanfaatkannya secara optimal dalam membantu proses belajar mengajar di kelas dalam jaringan. Pengabdian kepada masyarakat mengenai optimalisasi Google Classroom ini juga dilaksanakan di Subang dengan alasan kurangnya kemampuan guru dalam literasi digital. Pengabdian tersebut dilakukan pada guru-guru SMP di Subang pun dinilai efektif untuk memberikan gambaran holistik penggunaan platform sehingga permasalahan dalam pembelajaran virtual menjadi lebih variatif dan tidak memberatkan guru (El Fauziah, Suryani, \& Syahrizal , 2019).

Berdasarkan beberapa temuan penelitian menyatakan bahwa penerapan online learning mempunyai dampak positif dalam proses pembelajaran. Pertama, Hoi, Sahoo, Lu, Zhao (2018) mengemukakan bahwa online learning sangat efisien dalam implementasinya karena sistem dan konsep yang dapat digunakan dalam skala besar dengan kebutuhan finansial yang relatif murah. Penelitian selanjutnya dikemukakan oleh Mitchel\&Forer (2010) yang menyatakan bahwa penggunaan online learning untuk mahasiswa semester 
Pelatihan Dan Pendampingan Bagi Guru Bahasa Inggris Dalam Optimalisasi Platform Google Classroom Pada Proses Kegiatan Belajar Daring Berbicara Bahasa Inggris

Luthfiyatun Thoyyibah, Ratnawati, Desi Nurani

pertama pada perguruan tinggi pada jurusan Geografi memberikan respon yang positif terhadap penggunaan online learning daripada perkuliahan hanya murni menggunakan tatap muka ataupun sebaliknya pembelajaran daring saja.

Beberapa kegiatan pengabdian yang telah dilakasanakan kebanyakan membahas kegunaan Google Classroom bagi guru dan siswa di level SMP. Namun, berdasarkan penelitian terdahulu dan kegiatan sebelumnya, belum ada pengabdian yang menyandingkan antara pelatihan dan pendampingan penggunaan platform Google Classroom disertai dengan konsep menejemen kelas secara virtual pada kelas berbicara Bahasa Inggris. Maka dari itu, pengabdian ini layak untuk dilaksanakan untuk menambah referensi topik terkait.

\section{BAHAN DAN METODE}

Khalayak sasaran dalam kegiatan pengabdian kepada masyarakat adalah guru bahasa Inggris pada tingkat Sekolah Menengah Pertama (SMP) di Kabupaten Ciamis yang khususnya mengimplementasikan platform pembelajaran Google Classroom dan praktik langsung dalam pemanfaatan aplikasi Google form dan screencastify dalam pengajaran keterampilan berbicara bahasa Inggris. Hal tersebut telah dilaksanakan dalam bentuk pelatihan daring (dalam jaringan). Jumlah peserta pelatihan dan pendampingan yang terlibat adalah 60 guru yang memiliki latar belakang variative yakni asal sekolah, lama pengalaman mengajar, status profesionalisme, umur, jenis kelamin, dan latar belakang siswa serta fasilitas sekolah.

Sekaitan dengan tujuan dan manfaat kegiatan pengabdian pada bagian sebelumnya, dalam mewujudkan hal tersebut untuk meningkatkan kualitas pendidikan dalam jaringan pada proses kegiatan belajar dan mengajar dalam jaringan (online), tim pengusul melakukan beberapa langkah sebagai berikut;

1. Menyebarkan angket kepada guru bahasa Inggris dalam kawasan yang telah disebutkan pada paparan khalayak sasaran dalam hal penggunaan platform pembelajaran untuk mendukung kegiatan pembelajaran dalam jaringan (daring) mata pelajaran bahasa Inggris khususnya keterampilan berbicara.

2. Menganalisis sebaran angket yang telah terkumpul kembali.

3. Menghubungi para guru yang menggunakan platform yang dimaksudkan dalam pengabdian kali ini yaitu Google Classroom untuk menginformasikan topik pelatihan.

4. Mengkoordinasikan jadwal pelatihan dan pendampingan online dengan kesiapan waktu para calon peserta pelatihan. 
5. Mempersiapkan materi pelatihan dan pendampingan agar tepat sasaran sesuai dengan topik pengabdian yang dilaksanakan.

6. Menyelenggarakan pelatihan dan pendampingan dengan materi:

a. Optimalisasi penggunaan platform Google Classroom

b. Konsep pengelolaan kelas online pada platform Google Classroom

c. Pengenalan aplikasi screencastify untuk mendukung konsep pembelajaran daring yang inovatif dan menciptakan interkasi asynchronous antara guru dengan siswa, maupun, siswa dengan siswa lain.

\section{HASIL DAN PEMBAHASAN}

Kegiatan pengabdian ini dilaksanakan selama tiga hari, mulai taggal 18 sampai dengan 20 Januari 2021 secara online dengan pemnfaatan aplikasi Zoom Cloud Meeting dengan partisipasi aktif sebanyak 60 guru Bahasa Inggris SMP di Kabupaten Ciamis. Seperti penjelasan pada bagian pendahuluan, berdasarkan analisis data dan kebutuhan, beberapa permasalahan guru ditemukan yakni; (1) kesulitan mengatur kelas secara online, (2) kurangnya aktifitas dalam pembelajaran daring, (3) kurangnya media pembelajaran dan pembelajaran yang hanya teacher-centered learning sehingga kegiatan ini bertujuan untuk memberikan pelatihan dan pemdampingan bagi guru-guru bahasa Inggris yang mengajar di level SMP dalam hal pengoptimalisasian platform Google Classroom dalam pembelajaran berbicara bahasa Inggris.

Kegiatan pengabdian diawali dengan pemberian penjelasan oleh pemateri pertama dengan beberapa materi yakni: (1) Pengenalan jenis-jenis metode dan strategi pembelajaran Bahasa Inggris secara daring, (2) Pengelolaan kelas secara online baik synchronous dan asynchronous, (3) Persiapan kelas daring secara administratif dan akademik, (4) Penilaian kelas online baik pada pertemuan synchronous dan asynchronous, dan (5) Pola interaksi antara guru dengan mahasiswa serta mahasiswa satu dengan lainnya. Proses kegiatan berlangsung selama 2 jam (120 menit) yang terdiri dari pemaparan materi oleh Desi Nurani, M.Pd dan dilanjutkan dengan sesi tanya jawab secara interaktif dari pemateri dengan peserta kegiatan.

Berdasarkan data kualitatif selama proses kegiatan berlangsung, peserta kegiatan memiliki antusiasme positif karena mereka mendapatkan pencerahan dan inspirasi tentang bagaimana cara mengelola kelas dengan menggunakan platform Google Classroom, mempersiapkan piranti administratif dan akademik, interaksi kelas dan penilaian kelas secara online. Selanjutnya, pada sesi tanya jawab, beberapa pertanyaan juga diutarakan 
Pelatihan Dan Pendampingan Bagi Guru Bahasa Inggris Dalam Optimalisasi Platform Google Classroom Pada Proses Kegiatan Belajar Daring Berbicara Bahasa Inggris

Luthfiyatun Thoyyibah, Ratnawati, Desi Nurani

oleh peserta kegiatan. Pertanyaan pertama terakit dengan penggunaan Google Form yang belum pernah diimplementasikan dalam pengecekan kehadiran siswa selama proses belajar dan mengajar. Pada kesempatan tersebut, pemateri memberikan panduan langkah-langkah membuat Google Form untuk merekam kehadiran siswa dan mempraktekkan bagaimana membuatnya dan menautkan ke Google Classroom. Aplikasi ini dinilai efektif dibandingkan harus mengecek nama siswa satu persatu karena time consuming dan resiko terlewat lebih tinggi. Hal ini sejalan dengan penelitian yang dilakukan Ulum \& Fantiro (2019). Penggunaan Google Apps termasuk Google Form ini memberikan manfaat besar di dunia pendidikan umunya, pada teknis pembuatan daftar hadir kelas online khususnya. Pertanyaan kedua terkait pola atau strategi pengelompokan siswa dalam belajar online. Pemateri menjelskan bahwa pengelompokan dapat dilakukan dengan pemanfaatan fitur WhatsApp ataupun aplikasi yang ada pada Google Classroom dengan pemanfaatan fitur assign ke mahasiswa yang diinginkan dalam satu kelompok.

\section{Gambar 1}

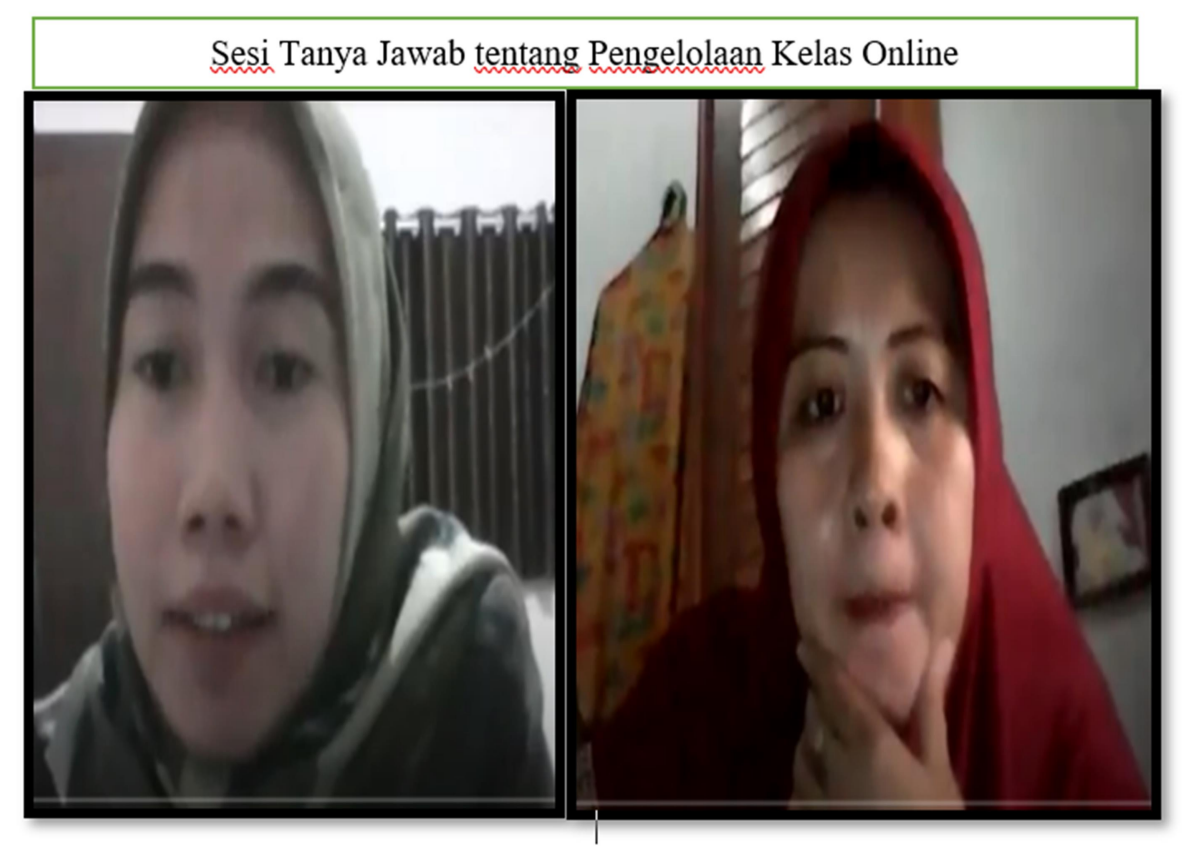

Gambar 1. Sesi Tanya Jawab tentang Pengelolaan Kelas Online

Pengabdian hari kedua diisi oleh dua pemateri yakni Luthfiyatun Thoyyibah, M. Pd dan Ratnawati, M. Pd. Cakupan materinya adalah pemanfaatan aplikasi yang bisa ditautkan dengan Google Classroom yang mendukung interaksi guru dengan siswa dalam pembelajaran berbicara Bahasa Inggris, yaitu aplikasi Screencastify. Melalui survei yang diberikan kepada peserta, didapat data bahwa 100\% guru belum pernah menggunakan aplikasi tersebut. 
Tabel 1. Respon Penggunaan Aplikasi Screencastify Sebelum PKM

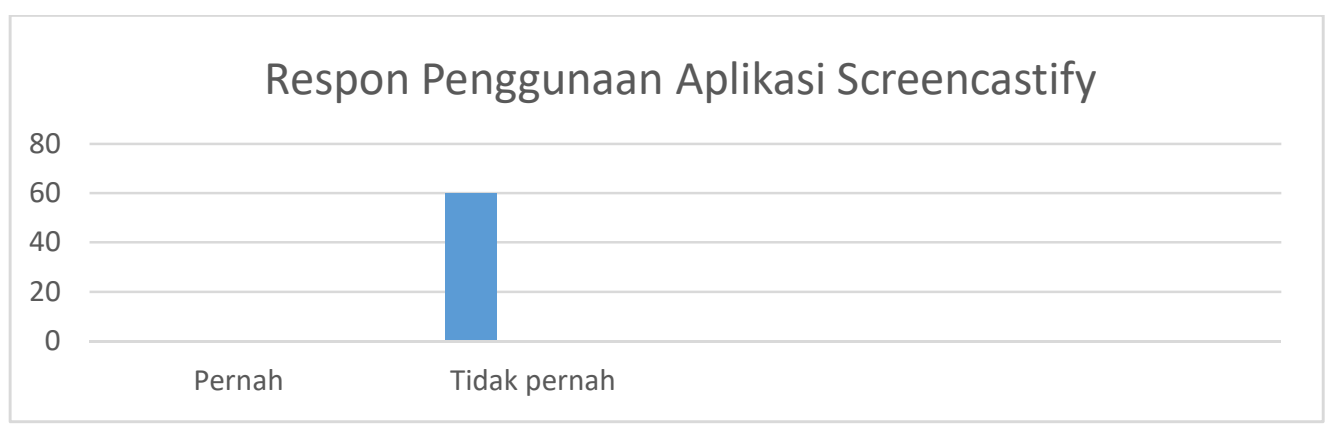

Berdasarkan informasi pada Tabel 1, pemateri memulai dengan penjelasan karakterisstik aplikasi dilanjutkan dengan langkah-langkah menggunakan aplikasi Screencastify. Karakteristik aplikasi Screencastify ini juga menjawab kebutuhan guru-guru tentang low-bandwidth aplikasi yang dicari. Hal tersebut dikaitkan dengan lokasi guru dan siswa yang kurang mendukung. Tempat tinggal guru dan siswa yang jauh dari stabilnya signal menjadikan aplikasi ini cocok digunakan. Disamping itu, durasi video yang maksimal 5 menit memudahkan guru untuk membagikannya pada tautan di Google Classroom. Dengan demikian, siswa juga tidak terlalu mendapatkan kesulitan dalam pengunduhan video tersebut.

Selanjutnya, fitur-fitur yang terdapat dalam aplikasi Screencastify juga ramah dan mengasyikkan untuk digunakan dalam proses belajar mengajar daring dengan latar belakang yang cukup heterogen. Berdasarkan www.screencastify.com (2020), mereka mempromosikan beberapa fitur yang dapat dimanfaatkan oleh pengguna sebagai berikut. Pertama, aplikasi tersebut dilengkapi dengan fitur perekam wajah sehingga originalitas karya lebih tinggi dan kehadiran siswa atau guru dapat dirasakan pada rekaman tersebut. Kedua, guru dan siswa dapat memanfaatkan fitur pen untuk memberikan catatan kecil dan emoticon sebagai penyemangat kepada siswa atau catatan penting dari siswa ke guru. Ketiga, aplikasi tersebut dilengkapi dengan fitur pemotong video sehingga pengguna aplikasi dapat mengedit video apa dan mana saja yang akan digunakan.

Pada sesi tersebut, kegiatan dibagi menjadi 2 (dua) kegiatan yakni pemaparan materi dan tanya jawab interaktif. Pada sesi pemaparan materi difokuskan pada pengenalan aplikasi screencastify dalam proses belajar mengajar khususnya keterampilan berbicara Bahasa Inggris, pengembangan aktifitas pembelajaran pada keterampilan berbicara Bahasa Inggris, pemanfaatan aplikasi sebagai kegiatan lanjutan dan tugas terstruktur kepada siswa serta tutorial peng-upload-an hasil karya ke platform Google Classroom. Sedangkan pada sesi tanya jawab, ada beberapa pertanyaan terkait dengan paparan mater. Pertanyaan 
Pelatihan Dan Pendampingan Bagi Guru Bahasa Inggris Dalam Optimalisasi Platform Google Classroom Pada Proses Kegiatan Belajar Daring Berbicara Bahasa Inggris

Luthfiyatun Thoyyibah, Ratnawati, Desi Nurani

pertama, peserta kegiatan bertanya mengenai bagaimana cara mengembangkan aktivitas pembelajaran keterampilan berbicara Bahasa Inggris dengan pemanfaatan aplikasi Screencastify. Pada kesempatan tersebut pemateri menyarankan bahwa guru-guru dapat beracuan pada SK (Standar Kompetensi), KI (Kompetensi Inti), Tujuan Pembelajaran dan desain pembelajaran yang akan diajarkan. Jika sudah ditentukan, guru dapat mulai melakukan proses perekaman aktivitas pembelajaran yag nantinya digunakan sebagai materi pembelajaran online. Selanjutnya, pertanyaan kedua terkait dengan ideal waktu persiapan yang harus dilaksanakan oleh guru sehingga video dan aktivitas pembelajaran dapat optimal. Pemateri menjawab bahwa persiapan yang harus dilaksanakan oleh guru memang lebih lama daripada pembelajaran secara tatap muka. Tidak ada ideal waktu dalam proses persiapan kegiatan belajar mengajar, semua itu dikembalikan dengan kondisi masing-masing guru dan kebutuhan guru tersebut.

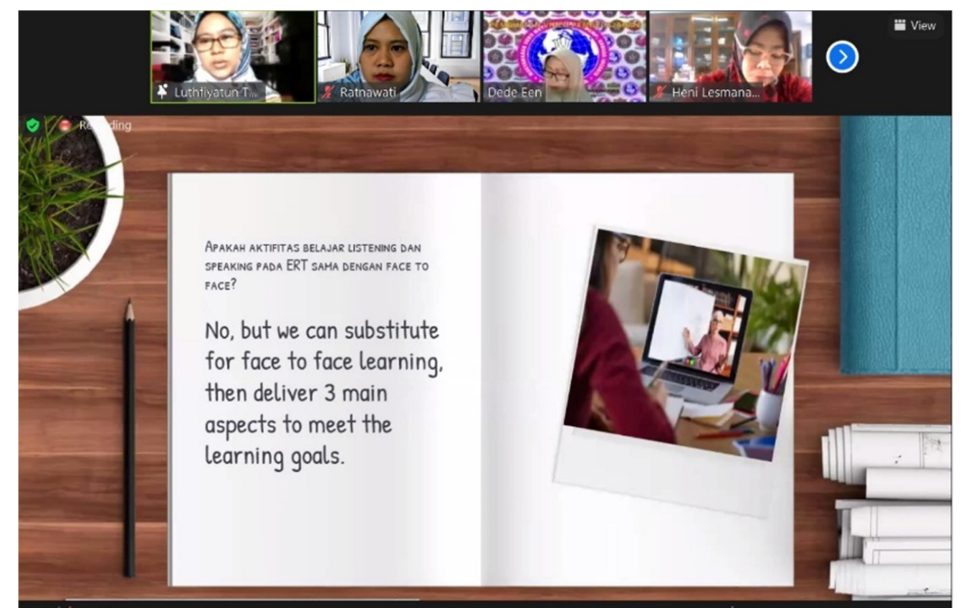

\section{Gambar 2. Proses Paparan Materi tentang Pemanfaatan Screencastify dalam kelas Berbicara Bahasa Inggris}

Dari hasil data yang ditemukan, peserta kegiatan merasa senang dengan adanya aplikasi tersebut karena siswa juga bisa melakukan perekaman video untuk tugas dan latihan berbicara bahasa Inggris untuk kemudian dilampirkan dalam Google Classroom. Jadi, aplikasi ini bermanfaat bagi guru dan siswa. Respon positif juga terlihat dari komentar pendapat dan saran yang menyatakan bahwa para peserta merasa kebutuhannya terpenuhi dengan gambaran penggunaan aplikasi untuk mendukung kegiatan berbicara bahasa Inggris yang bisa di tautkan dengan Google Classroom. Hasil ini mendukung hasil data yang telah dilakukan oleh Henry et al., (2020) yang menyatakan bahwa aplikasi Screencastiy mudah digunakan dan efektif untuk proses belajar mengajar. Terlepas dari 
penggunaan aplikasi Screencastify pada pembelajaran berbicara Bahasa Inggris, pada umumnya platform Google Classroom juga memiliki efektifitas dan keramahan dalam penggunaannya sehingga kegiatan ini difokuskan pada platform tersebut (Amin \& Sundari, 2020) and (Abid Azhar \& Iqbal, 2018).

\section{KESIMPULAN DAN SARAN}

Kegiatan pelatihan dan pendampingan bagi guru bahasa Inggris ini merupakan kegiatan lanjutan pengembangan teori belajar berbasis online kategori asynchronous yang disarankan oleh Menteri Pendidikan dan Kebudayaan Indonesia. Setelah dilaksanakan pelatihan dan pendampingan ini, data menunjukkan bahwa guru bahasa Inggris di wilayah kabupaten Ciamis ini memiliki pengetahuan dan kemampuan untuk mengembangkan kegiatan belajar melalui platform Google Classroom diselaraskan dengan pengecekan kehadiran dengan Google form juga dengan menejemen kelas yang tetap dilaksanakan apik oleh guru.

Diharapkan peserta pelatihan dan pendampingan bisa terus menggunakan aplikasi Screencastify untuk di tautkan pada Google Classroom juga terus mengeksplorasi penggunaan beberapa fitur yang ada di Google Classroom.

\section{UCAPAN TERIMA KASIH}

Dengan selesainya PKM ini penulis menyampaikan terima kasih kepada Ketua LPPM Universitas Galuh, Ketua MGMP SMP Kabupaten Ciamis, juga seluruh guru bahasa Inggris peserta kegiatan PKM ini yang telah ikut serta dalam mensukseskan kegiatan ini.

\section{DAFTAR PUSTAKA}

Abid Azhar, K., \& Iqbal, N. (2018). Effectiveness of Google Classroom: Teachers' Perceptions. Prizren Social Science Journal , 2(2), 52-66.

Amin, M. F., \& Sundari, H. (2020). Efl students' preferences on digital platforms during emergency remote teaching: video conference, lms, or messenger application? Studies in English Language and Education , 7(2), 362-378.

CNN Indonesia. (2020). NAdiem Buat Program "Belajar dari Rumah". Jakarta : CNN Indonesia .

El Fauziah, U. N., Suryani, L., \& Syahrizal , T. (2019). PENERAPAN GOOGLE CLASSROOM DALAM PEMBELAJARAN BAHASA INGGRIS KEPADA GURU-GURU BAHASA INGGRIS SMP DI SUBANG. Jurnal Pengabdian Kepada Masyarakat IKIP Siliwangi, Vol 2(2). 
Elizabeth , H., Hinshaw, R., Al Bataineh, A., \& Bataineh, M. (2020). Exploring Teacher and Student Perceptions on the Use of Digital Conferencing Tools. The Turkish Online Journal of Educational Technology -, Vol 19 (3).

Hodges, C., Moore, S., Lockee, B., Trust, T., \& Bond, A. (2020). The Difference Between Emergency Remote Teaching and Online Learning. Educause, 1-2. Retrieved from https://er.educause.edu/articles/2020/3/the-difference-between-emergency-remoteteaching-and-.

Hoi, S., Sahoo, D., Lu, J., \& Zhao, P. (2018). Online Learning: A Comprehensive Survey. SMU Technical Report 1, 1-100.

Latif, S. (2016). Learning Engagement in Virtual Environmnet. International Journal of Computer Application, 148(11), 7-13. Retrieved from https://www.ijcaonline.org/archives/volume148/number11/25799- 2016911289 .

Mitchell, P., \& Forer , P. (2010). Blended learning: The Perceptions of First-yesr Geography Students. Journal of Geography in Higher Education, Vol 34(1), 77-89.

Rahiem, M. D. (2020). The emergency remote learning experience of university students in Indonesia amidst the COVID-19 crisis. International Journal of Learning, Teaching and Educational Research, 19(6), 1-26. Retrieved from https://doi.org/10.26803/ijlter.19.6.1.

Ulum, B., \& Fantiro, F. A. (2019). Pemanfaatan Google Apps di Era Literasi Digital Pada Siswa Sekolah Dasar. ELEMENTA Jurnal, Vol 1 (1), 1-8 .

www.screencastify.com. (2020). Screencastify overview. Retieved from https://chrome.google.com/webstore/detail/screencastify-screenvide/mmeijimgabbpbgpdklnllpncmdofkcpn. 